\title{
$\begin{array}{lllllllll}\text { I } & \mathrm{N} & \mathrm{S} & \mathrm{T} & \mathrm{I} & \mathrm{T} & \mathrm{U} & \mathrm{T} & \mathrm{E}\end{array}$
}

\section{Wanting More but Working Less: Involuntary Part-Time Employment and Economic Vulnerability}

\author{
REBECCA GLAUBER
}

$\mathrm{P}$ art-time employment increased dramatically during the recent recession for both men and women. Individuals work part time for many reasons. Some do so to care for children and elderly family members. Others do so because they are in school. Yet others work part time because they cannot find full-time work. This last reason may be a cause of concern for both workers and employers, as well as those interested in the long-term productivity and efficiency of the U.S. economy. Involuntary part-time employment (or underemployment) is concentrated among relatively disadvantaged groups, such as African Americans and Hispanics, recent immigrants, and high school dropouts. ${ }^{1}$ The effects of the recent recession look more severe when we consider both unemployment and underemployment. ${ }^{2}$ In 2012, 8.3 percent of the total labor force was unemployed, but an additional 5.7 percent was underemployed. ${ }^{3}$

Using data from the Current Population Survey (CPS), a national survey of U.S. households, this brief finds a strong association between involuntary part-time employment and economic vulnerability. Not only do part-time workers bring home less money than full-time workers, but they also tend to have fewer fringe benefits. ${ }^{4}$ Involuntary part-time workers face even greater penalties. As this brief outlines, they are more likely to live in poverty and to experience sustained periods of unemployment.

These are not problems with easy solutions. Nevertheless, there are two types of policies that may help alleviate such entrenched economic vulnerability-policies that improve the quality of part-time positions and policies that lower the number of Americans in involuntary part-time employment. This brief first presents research findings and then discusses these policies as well as the relationship between involuntary parttime employment and the Patient Protection and Affordable Care Act, given its potential effects on part-time workers' job opportunities and access to health insurance coverage.

\section{Key Findings}

Involuntary part-time employment is defined as working fewer than 35 hours per week because full-time work is unavailable.

- The single largest five-year increase in involuntary part-time employment since the 1970s occurred between 2007 and 2012.

- The involuntary part-time employment rate more than doubled between 2007 and 2012. For women, it rose from 3.6 percent to 7.8 percent. For men, the rate increased from 2.4 percent in 2007 to 5.9 percent in 2012.

- While the unemployment rate has slowly fallen since 2010, the rate of workers in involuntary part-time positions has remained relatively constant.

- Involuntary part-time employment is a key factor in poverty. In 2012, one in four involuntary part-time workers lived in poverty, whereas just one in twenty full-time workers lived in poverty.

- In 2012, involuntary part-time workers were nearly five times more likely than full-time workers to have spent more than three months of the previous year unemployed. 


\section{Defining Part-Time Employment}

The CPS includes two pertinent questions: (1) "Do you normally work a full-time or part-time schedule?" and (2) "What is the reason for your part-time employment?" From these two questions and following Bureau of Labor Statistics (BLS) definitions, these groups of workers were created:

- Full-time workers: Workers who normally work full time (35 or more hours per week).

- Involuntary part-time workers: Those who normally work part time because of poor economic conditions or an inability to find full-time work.

- Voluntary part-time workers: Those who normally work part time by choice.

- Other part-time workers: Those who work part time for other unspecified reasons.

\section{Although Unemployment Has Fallen Since 2010, Involuntary Part-Time Employment Has Remained Relatively Constant}

Involuntary part-time employment rates doubled during the recession and reached 6.5 percent by $2009 .{ }^{5}$ The recent trends for women (Figure 1) and men (Figure 2) are similar, but they are presented separately because research shows that there are many gender differences in labor market outcomes. The rate for women more than doubled between 2007 and 2012, from 3.6 percent to 7.8 percent, and the rate for men also more than doubled from 2.4 percent in 2007 to 5.9 percent by 2012 . These increases represent the single largest five-year increase since the mid-1970s. Moreover, the increase in involuntary part-time employment accounts for nearly all of the increase in total part-time employment during the recession. While the unemployment rate has fallen since 2010, the involuntary part-time employment rate has remained relatively unchanged.

For women, voluntary part-time employment has decreased steadily since the 1970 s, while for men it has remained relatively flat. However, during the 1990s-a period of economic expansion - the involuntary part-time employment rate declined for both men and women. As Figures 1 and 2 indicate, involuntary part-time employment tends to increase during recessionary periods.
Figure 1. PerCent OF EMPloyed WOMEN Ages 18-64 WHO SPENT THE LAST YEAR WORKING PART TIME FOR VOLUNTARY, INVOLUNTARY, AND OTHER REASONS (1976-2012)

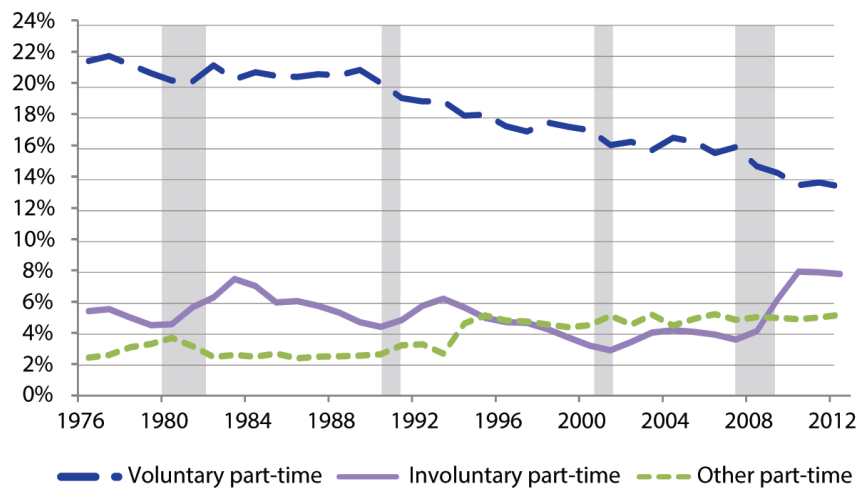

Source: Annual Social and Economic Supplement, Current Population Survey, 1976-2012 Note: The shaded bars reflect recessions.

Figure 2. PERCENT OF EMPLOYED MEN AGES 18-64 WHO SPENT THE LAST YEAR WORKING PART TIME FOR VOLUNTARY, INVOLUNTARY, AND OTHER REASONS (1976-2012)

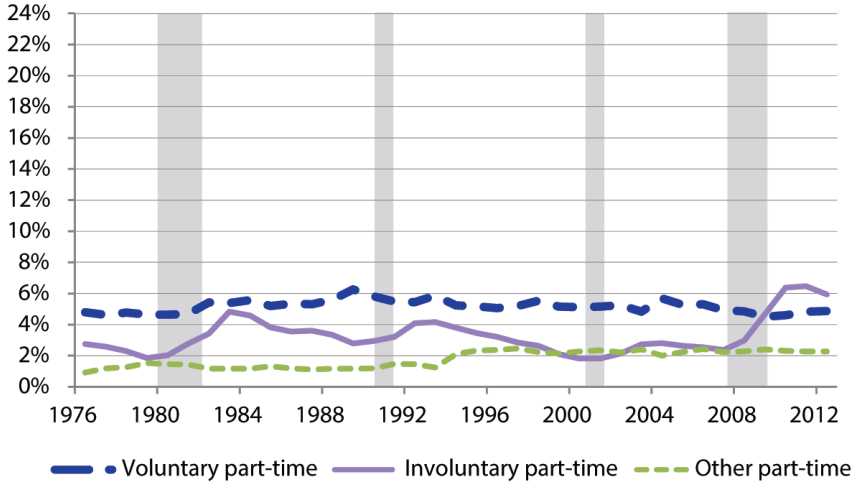

Source: Annual Social and Economic Supplement, Current Population Survey, 1976-2012 Note: The shaded bars reflect recessions.

\section{One in Four Involuntary Part-Time Workers Lives in Poverty, but Just One in Twenty Full-Time Workers Lives in Poverty}

In 2012, more than one-fourth of women who worked involuntarily part time lived in poverty, and more than one-half were low income, that is, living in families with total income below 200 percent of the federal poverty line (Figure 3 ). ${ }^{6}$ These figures far exceed those for women who worked voluntarily part time (12 percent) or for other reasons (14 percent). 
Figure 3. Percent OF EMPLOYed WOMEN AGeS 18-64 WhO WERE POOR OR LOW-INCOME, BY WORK STATUS (2012)

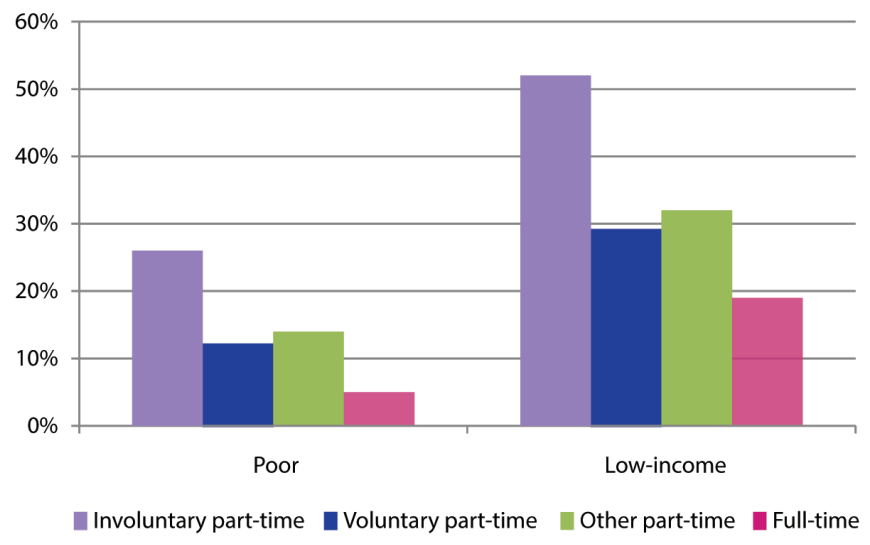

Source: Annual Social and Economic Supplement, Current Population Survey, 2012

For men, findings are similar. As shown in Figure 4, 23 percent who worked involuntarily part time lived in poverty, and 50 percent were low income. In contrast, just 12 percent of men who worked voluntarily part time lived in poverty, and 14 percent who worked part time for other reasons lived in poverty.

Among full-time workers, in contrast, 5 percent of women and 4 percent of men lived in poverty. In other words, women working part time involuntarily were 5.20 times more likely to live in poverty than women working full time. For men, the comparable figures were 5.75 times more likely. The situation for low-income status is also bleak. Involuntary part-time workers were nearly three times more likely to be low income than full-time workers.

Figure 4. Percent of EMPloyed Men Ages 18-64 Who WERE POOR OR LOW-INCOME, BY WORK STATUS (2012)

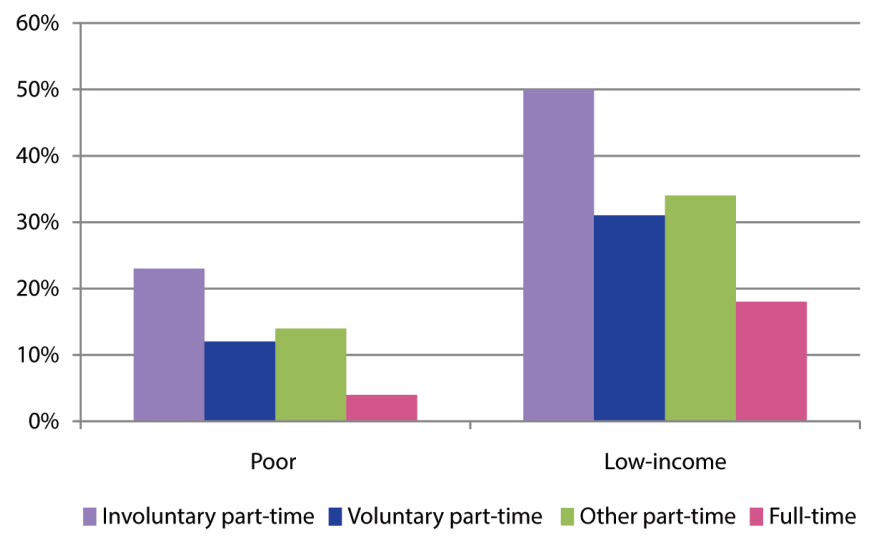

Source: Annual Social and Economic Supplement, Current Population Survey, 2012

\section{Involuntary Part-Time Workers Experience Sustained Periods of Unemployment}

Involuntary part-time employment is rarely stable. As Figures 5 and 6 show, in 2012, 24 percent of women and 31 percent of men who worked part time involuntarily spent a substantial portion (more than thirteen weeks) of the prior year unemployed. In contrast, just 5 percent of women and 8 percent of men who worked part time voluntarily were unemployed for significant spells. Put another way, women who worked part time involuntarily were five times more likely to have spent a substantial portion of the year unemployed than those who worked part time voluntarily. Their male counterparts were nearly four times more likely to have had long stints of unemployment in the prior year. In contrast, only 5 percent of women and 6 percent of men who worked full time spent more than thirteen weeks of the year unemployed.

Figure 5. Percent OF EMPloyed WOMEN AgeS 18-64 WHO SPENT MORE THAN THIRTEEN WEEKS OF THE PREVIOUS YEAR UNEMPLOYED, BY WORK STATUS (2012)
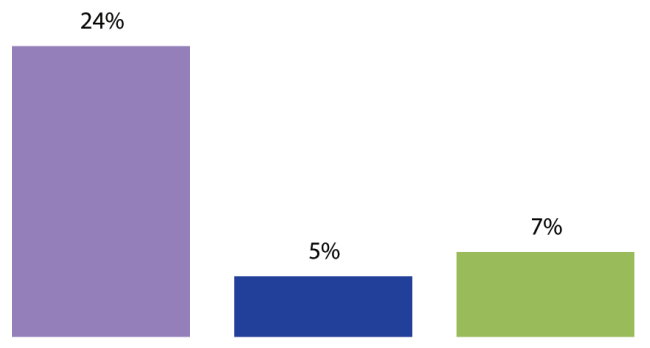

$5 \%$

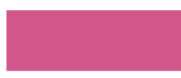

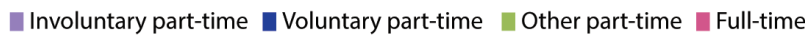
Source: Annual Social and Economic Supplement, Current Population Survey, 2012

Figure 6. PERCENT OF EMPLOYED MEN AgeS 18-64 WHO SPENT MORE THAN THIRTEEN WEEKS OF THE PREVIOUS YEAR UNEMPLOYED, BY WORK STATUS (2012)

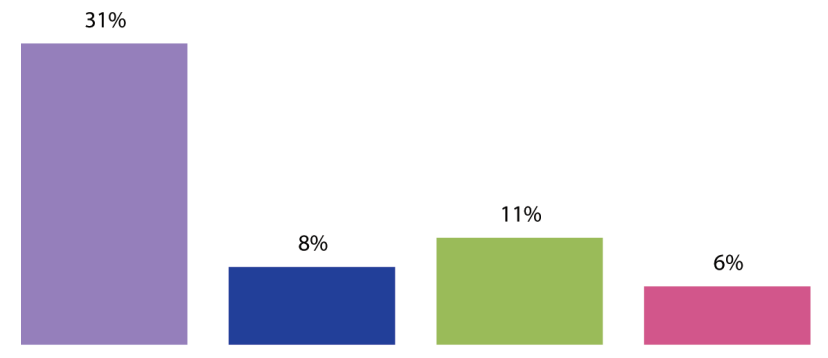

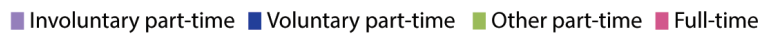




\section{Involuntary Part-Time Workers Have Less Income than Other Workers}

In 2012, the median family income for women working part time involuntarily $(\$ 36,060)$ was lower than that for women working part time voluntarily $(\$ 68,013)$ (Table 1$)$. The situation for men was comparable. The amounts in Table 1 reflect total family income, not individual earnings, as total family income tends to be a more appropriate measure of economic hardship.

In part, differences in family income reflect marital status and the presence of another earner in the family. Just 39 percent of women working part time involuntarily were married in 2012, compared with 54 percent working part time voluntarily, 49 percent working part time for other reasons, and 52 percent working full time. ${ }^{7}$ Similarly, 31 percent of men who worked part time involuntarily were married in 2012, compared with 23 percent working part time voluntarily, 31 percent working part time for other reasons, and 60 percent working full time.

The median income for men who worked part time voluntarily or for other reasons was lower than that for women. These findings align with federal statistics. In 2012, the median weekly earnings were $\$ 281$ for women working part time and $\$ 273$ for men. ${ }^{8}$

\section{Involuntary Part-Time Economic Penalties Are Consistent Across Places}

Table 2 shows that, among women, 29 percent of involuntary part-time workers living in rural areas and 25 percent in urban areas were poor (see Box 1 on the next page). In both rural and urban areas, involuntary part-time female workers were about four to five times more likely than fulltime female workers to live in poverty ( 29 percent versus 7 percent in rural areas, and 25 percent versus 5 percent in urban areas). The trends for men are similar.

\section{Part-Time Work and Policy Dilemmas}

Involuntary part-time employment spiked during the recent recession. As this analysis shows, women and men who worked part time because they could not find full-time employment were much more likely to live in poverty and to have unstable employment than other part-time and full-time workers. As others have argued, the recent recession looks more severe when we consider both unemployment and underemployment. ${ }^{9}$ What others haven't explored, however, is how underemployment in the recent recession is strongly correlated with economic hardship and vulnerability.

The disparities between involuntary part-time workers and full-time workers are striking. Among women, median family income was $\$ 31,928$ greater for full-time workers than for involuntary part-time workers. Among men, median family income was $\$ 35,000$ greater. Both men and women working part time involuntarily were more than five times as likely to live in poverty as those working full time. They were nearly three times more likely to be low income. Men and women working part time involuntarily were approximately five to six times more likely to have spent a substantial portion of the year unemployed than their counterparts working full time.

On the surface, part-time employment is not necessarily problematic. It offers many workers flexibility and balance in their work and personal lives. One recent study found that nearly 40 percent of mothers who work full time would like to work part time, and more than 60 percent of mothers who work part time would like to continue working part time. ${ }^{10}$ Part-time employment becomes problematic, however, when it is systematically or involuntarily associated with labor market disadvantages.

This brief raises larger questions about the constraints on workers' choices. A first question is whether the distinction between voluntary and "other" part-time work is conceptually meaningful, and if there are gender differences in how individuals think about their work choices. Are women, for example, more likely than men to conceive of their part-time work as voluntary when they work part time to care for other family members?

TABle 1. FAMily InCOME AND MARITAL STATUS FOR PART-TIME AND FULL-TIME WORKERS AGES 18-64 (2012)

\begin{tabular}{|c|c|c|c|c|c|c|c|c|}
\hline & \multicolumn{4}{|c|}{ Women } & \multicolumn{4}{|c|}{ Men } \\
\hline & $\begin{array}{l}\text { Involuntary } \\
\text { Part-Time }\end{array}$ & $\begin{array}{l}\text { Voluntary } \\
\text { Part-Time }\end{array}$ & $\begin{array}{c}\text { Other } \\
\text { Part-Time }\end{array}$ & Full-Time & $\begin{array}{l}\text { Involuntary } \\
\text { Part-Time }\end{array}$ & $\begin{array}{l}\text { Voluntary } \\
\text { Part-Time }\end{array}$ & $\begin{array}{c}\text { Other } \\
\text { Part-Time }\end{array}$ & Full-Time \\
\hline Median family income in 2011 dollars & $\$ 36,060$ & $\$ 68,013^{a c}$ & $\$ 63,000^{\text {ac }}$ & $\$ 67,988$ ac & $\$ 36,000$ & $\$ 60,250^{b c}$ & $\$ 57,236^{b c}$ & $\$ 71,000^{\mathrm{bc}}$ \\
\hline Percent married & $39^{c}$ & $54^{\text {ac }}$ & $49^{\text {ac }}$ & $52^{\mathrm{ac}}$ & $31^{c}$ & $23^{b c}$ & $31^{\mathrm{c}}$ & $60^{\mathrm{bc}}$ \\
\hline
\end{tabular}

Source: Annual Social and Economic Supplement, Current Population Survey, 2012.

Notes: ${ }^{a}$ indicates that among women, the figure is significantly different from involuntary part-time workers at $p<.05 ;{ }^{b}$ indicates that among men, the figure is significantly different from involuntary part-time workers at $p<.05$, and ${ }^{c}$ indicates that there is a significant gender difference at $p<.05$. 
TABLE 2. ECONOMIC INDICATORS FOR PART-TIME AND FULL-TIME WORKERS AGES 18-64 BY PLACE OF RESIDENCE (2012)

\begin{tabular}{|c|c|c|c|c|c|c|c|c|}
\hline & \multicolumn{4}{|c|}{ Women } & \multicolumn{4}{|c|}{ Men } \\
\hline & $\begin{array}{l}\text { Involuntary } \\
\text { Part-Time }\end{array}$ & $\begin{array}{l}\text { Voluntary } \\
\text { Part-Time }\end{array}$ & $\begin{array}{c}\text { Other } \\
\text { Part-Time }\end{array}$ & Full-Time & $\begin{array}{l}\text { Involuntary } \\
\text { Part-Time }\end{array}$ & $\begin{array}{l}\text { Voluntary } \\
\text { Part-Time }\end{array}$ & $\begin{array}{c}\text { Other } \\
\text { Part-Time }\end{array}$ & Full-Time \\
\hline \multicolumn{9}{|l|}{ URBAN } \\
\hline Percent of workers in each work category & 8 & 14 & 5 & 74 & 6 & 5 & 2 & 87 \\
\hline Percent poor & 25 & 11 & 14 & 5 & 23 & 12 & 13 & 4 \\
\hline Percent low-income & 52 & 28 & 30 & 18 & 50 & 30 & 32 & 17 \\
\hline $\begin{array}{l}\text { Percent spending more than } 13 \text { weeks } \\
\text { unemployed }\end{array}$ & 24 & 5 & 7 & 5 & 30 & 8 & 10 & 6 \\
\hline \multicolumn{9}{|l|}{ RURAL } \\
\hline Percent of workers in each work category & 8 & 15 & 5 & 72 & 6 & 4 & 2 & 88 \\
\hline Percent poor & 29 & $14^{*}$ & 18 & $7 *$ & 27 & 13 & 17 & $5^{*}$ \\
\hline Percent low-income & 54 & $33 *$ & $42 *$ & $24 *$ & 53 & 15 & $47^{*}$ & $21^{*}$ \\
\hline $\begin{array}{l}\text { Percent spending more than } 13 \text { weeks } \\
\text { unemployed }\end{array}$ & 23 & 5 & 7 & 5 & 32 & 8 & 14 & 7 \\
\hline
\end{tabular}

Source: Annual Social and Economic Supplement, Current Population Survey, 2012.

Note: ${ }^{*}$ indicates that the percentage for urban workers is significantly different from that for rural workers at $p<.05$.

Another important question for policy makers and the public is whether involuntary part-time employment will remain high or will return to pre-recession levels. Unemployment has slowly declined over the past couple of years, but involuntarily employment has not.

In general, part-time positions offer lower pay, fewer benefits, and less job security than full-time positions. ${ }^{11}$ Unemployment benefits for part-time workers also vary considerably depending on where a worker lives. Policies that increase the quality of part-time positions, such as unemployment insurance for parttime workers, may go far in alleviating the economic penalties associated with involuntary part-time employment. As economist Chris Tilly has argued, "Federal law should ensure that part-time workers receive a benefit package equivalent to that of full-timers, benefits that would be prorated to reflect the differences in hours worked." 12 These types of policies that encourage high-quality part-time positions would also cut down on the number of Americans working in involuntary part-time positions, as employers would no longer stand to gain as much from employing part-time workers.

The Patient Protection and Affordable Care Act (ACA), passed by Congress and signed into law by President Obama in 2010, will extend health insurance to more than 30 million people. The act mandates that, by 2014, employers with fifty or more full-time workers (including all workers averaging thirty or more hours per week) offer affordable health insurance or pay a penalty of $\$ 2,000$ per worker. Critics charge that this mandate will essentially force employers to reduce their employees' work hours below the 30-hour threshold, but in Massachusetts, involuntary part-time employment did not increase with the passage of health care reform. This point cannot be overemphasized. Massachusetts implemented health care reform in
2006 and mandated that employers with ten or more full-time workers provide a "fair and reasonable" amount toward health insurance or pay a penalty of \$295 per worker. Between 2006 and 2010, full-time employment declined by 2.8 percentage points in Massachusetts and by 2.7 percentage points in states with comparable employment levels, and full-time employment declined by a significantly larger percentage ( 3.6 percentage points) in the rest of the nation. ${ }^{13}$

Finally, it is important to note that this analysis does not address cause and effect. Involuntary part-time employment may lead to poverty and employment instability. It may also be the case that other unmeasured factors are correlated with both involuntary part-time employment and poverty. In either case, involuntary part-time workers and their families are in more economically precarious positions than other workers.

Box 1: Definition of the Terms Rural and Urban Definitions of rural and urban vary among researchers and the sources of data they use. Data for this brief come from the Current Population Survey, which indicates whether or not each household is located in a metropolitan area. The Office of Management and Budget defines a metropolitan area as: (1) a central county (or counties) containing at least one urbanized area with a population of at least 50,000 people, and (2) the counties that are socially and economically integrated with the urbanized area, as measured by commuting patterns. In this brief, urban refers to such metropolitan places, and rural refers to nonmetropolitan places outside these boundaries. 


\section{Data}

The Current Population Survey (CPS) is a monthly household survey conducted by the U.S. Bureau of Labor Statistics (BLS) and the U.S. Census Bureau. The survey was initially designed in the 1940s to measure unemployment. Since then, it has been fielded every month to a sample of about 50,000 households, and it asks a number of questions on labor force behavior.

The CPS asks about part-time employment for the week prior to the survey and for the previous calendar year. Numerous studies have used both measures of part-time employment, and they tend to return similar results. This analysis uses measures pertaining to the previous calendar year because the measure of voluntary part-time employment is more consistent.

All differences are significant at the 5 percent level, and all data are weighted to account for the complex survey design. All analyses exclude individuals living in group quarters and those under age 18 or over age 64 .

\section{E N D N O TES}

1. Andrew Sum and Ishwar Khatiwada, "The Nation's Underemployed in the 'Great Recession' of 2007-09,' Monthly Labor Review, vol. 133 (2010): 3-15.

2. Justin R. Young, "Underemployment in Urban and Rural America, 2005-2012," Issue Brief No. 55 (Durham, NH: Carsey Institute, 2012).

\section{Young, "Underemployment."}

4. H. Luke Shaefer, "Part-Time Workers: Some Key Differences between Primary and Secondary Earners," Monthly Labor Review, vol. 3 (2009): 3-15.

\section{Ibid.}

6. The federal government defines poverty by comparing family income to published income thresholds for family size. In 2012, for example, a family of four was considered poor if their family income fell below $\$ 23,050$.

7. These figures reflect marital status rather than cohabitation, which could be higher for involuntary part-time workers.

8. U.S. Bureau of Labor Statistics, "Usual Weekly Earnings of Wage and Salary Workers, Fourth Quarter 2012" (Washington, DC: BLS, January 18, 2013).

9. Young, "Underemployment."

10. Pew Research Center Social and Demographic Trends, "The Harried Life of the Working Mother" (Washington, DC: Pew, 2009).
11. Chris Tilly, Short Hours, Short Shrift: Causes and Consequences of Part-Time Work (Washington, DC: Economic Policy Institute, 1990).

\section{Ibid, p. 24.}

13. Lisa Dubay, Sharon K. Long, and Emily Lawton, "Will Health Reform Lead to Job Loss? Evidence from Massachusetts Says No" (Washington, DC: Urban Institute, 2012).

\section{ABOUT THE AUTHOR}

Rebecca Glauber is an assistant professor of sociology and a faculty fellow at the Carsey Institute at the University of New Hampshire.

\section{A C K N O W L E D G M E N T S}

The author thanks Barbara Ray at Hired Pen; Ann Tickamyer at the Pennsylvania State University; and Curt Grimm, Laurel Lloyd, Beth Mattingly, Kristin Smith, Amy Sterndale, and Justin Young at the Carsey Institute for their helpful comments and suggestions.

\section{ANIVERSITY}

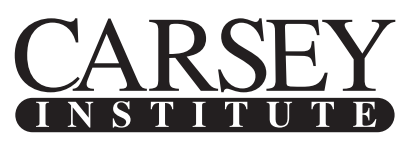

Building knowledge for families and communities

The Carsey Institute conducts policy research on vulnerable children, youth, and families and on sustainable community development. We give policy makers and practitioners timely, independent resources to effect change in their communities.

This work was supported by the Annie E. Casey Foundation, the W. K. Kellogg Foundation, and anonymous donors.

Huddleston Hall

73 Main Street

Durham, NH 03824

(603) $862-2821$

www.carseyinstitute.unh.edu 